\title{
Transfer Pricing And Taxation Implications Disclosure In Segmental Reporting: Malaysian Evidence
}

Mohammad Talha, (E-mail: mohammad.talha@mmu.edu.my), Multimedia University, Malaysia Syed Shah Alam, (E-mail: syed.shah.alam@mmu.edu.my), Multimedia University, Malaysia Abdullah Sallehhuddin, (E-mail: abdullah.sallehhuddin@mmu.edu.my), Multimedia University, Malaysia

\begin{abstract}
Transfer pricing has emerged as common practice among highly diversified companies. Company goes for either domestic transfer pricing or international transfer pricing for several distinctive reasons. While domestic transfer pricing aims for enhancing divisional autonomy and divisions' managers, international transfer pricing expects for less taxes, tariff, duties and excises. Therefore, international transfer pricing has significant taxation implication. With expansion of transfer pricing, financial statement users demand unconsolidated account to thoroughly evaluate specific segments' performance, track transfer pricing practices and the taxation implication on the companies. Due to these increasing demands, segmental reporting is impartially needed. The present paper highlights the (1) theoretical aspect of transfer pricing and its taxation implication and (2) the disclosure of transfer pricing and its taxation implication in Malaysian segmental reporting environment. A study of 80 companies listed on Malaysian Board has been conducted to evaluate the transfer pricing and its taxation implication disclosure in Malaysian's segmental reporting environment. As exploratory attempt, the study found that companies voluntarily disclose the basis of setting up transfer price. However, such disclosure is not adequate to assist performance evaluating and decision-making process as transfer price is only been reported in business segment, taxation implication has been disclosed as consolidated figure and moreover transfer pricing and its taxation implication is voluntary disclosure. Intensive effort should be carried out to improve those disclosures in future particularly by imposing mandated reporting for transfer pricing and its taxation implications. Further study shall be conducted to expand the sample, intensify segment report preparers' behavioral study and cross analysis between countries.
\end{abstract}

\section{INTRODUCTION}

egmental reporting involves breaking the company down into its constituent parts or segments and reporting financial information on a disaggregated basis for each segment (Gray and Roberts, 1989). Radebaugh and Gray (2002) further define segmental reporting as the counterpoint information that involves the disaggregating of consolidated financial statements. Meanwhile, Malaysian Accounting Standards Board (MASB) defines segmental information as information about an enterprise's different types of products and services and its operation in different geographical areas.

A company may segment its operation in various ways, with the two most common methods are segmentation by industry or type of business or often called line of business (LOB) and by geographical area. The amount of segment information provided by companies varies in terms of the items disclosed and the number of segments reported. These are influenced by the company's management discretion in defining its business activities, external reporting mechanism, different geographical area of operating and reporting standard set up by a the respective accounting bodies. 
Multinational and multi-diversified companies around the world are facing increasing pressure to disclose more segmental information in their financial report (Garrod, 2000). These pressures come from various parties such as International Accounting Standards Committee (IASC), Organization of Economic Cooperation Development (OECD) and Malaysian Accounting Standards Board (MASB) as well as from other users of companies' financial statement.

In recent years, companies throughout the world have diversified their activities. This diversification includes the process of venturing business in different locations or geographical areas. The study by Reed and Luffman (1986) found that the purposes of diversification range widely from risk reduction, discretional change, stabilization of earnings and increasing growth. It also helps companies to have more source of revenue instead of depending onto a particular business segment. This raised a question whether consolidated financial statements and aggregated accounting figures are adequate for companies' operations consisting of a number of activities in a variety of locations with different profitability potential, risks, rate of return and growth opportunities. Another reason that contributes to the complexities of the business operation nowadays is the merger and acquisition activity of a wide variety of business operations. Due to this problem, users of financial statements face difficulties in evaluating and assessing the companies, and predicting the future activities only from traditional financial statement such as income statement, balance sheet statement and owners' equity statement. In view of the complexity involved, segmental information disclosure is significantly needed.

Furthermore, pressures to disclose more segmental information is due to the fact that many users are affected directly by only one part of a company (Gray et al., 1989). For instance, employees' compensation is generally more directly dependent upon a performance of the specific part of the group with which they work than upon the performance of the group as a whole. Besides, host governments are interested in the performance of individual segment of the group that is located in their countries. Customers, suppliers and creditors are keen on a specific part of the companies' business activities. Therefore, they demand disaggregated information. In addition, stakeholders of multi-diversified companies need financial information to evaluate the past performance of companies and their future prospects. These can usually only be understood if the users know the importance of each class of business a geographical area in which the companies operate.

Segmental information, which might be imperfect, goes some way towards fulfilling these needs since different industries and countries have different profit potentials, growth opportunities and degrees of risk, different rates of investment returns and different capital needs (Gray et al., 1989). Besides, it is argued that consolidated accounts provide information that is too aggregated for users to assess the various risks and rewards associated with the individual components of the whole organization (Ronen and Livnat, 1988). Information on these risk and return differences is vital if the published accounts are to be represented faithfully (Solomons, 1989), a quality desired by most accounting bodies (Financial Accounting Standards Board, 1976).

There are however, exist special problems in evaluating the performance of reporting segments when goods or services are transferred from one division to another in order to manufacture finished products or from unit to another unit in different geographical area. A transfer price is the price charged when one segment of a company provides goods or services to another segment of the company. Transfer pricing has two different forms, that are domestic transfer pricing and international transfer pricing. For multi-diversified companies such as a multinational corporation (MNC), the objective of transfer pricing change as compared to domestic transfer pricing. International transfer pricing involves goods and services being transferred cross international borders. Thus, international transfer pricing focuses on minimizing taxes, duties, and foreign exchange risks, along with enhancing a company's competitive position and improving its relations with foreign government. The summary of transfer pricing objectives are graphically presented in Figure 1

From the foregoing discussion, it raised one important question that to be addressed in this paper. Do transfer pricing and its tax implication is adequately disclosed by segmental reporting? The discussion will focus on the disclosure of such information in the context of Malaysian segmental reporting practice. However, further explanation will also incorporate international perspective. This paper is organized into six parts. Part One discusses the background and the importance of segmental reporting. Part Two describes the theoretical aspect of transfer pricing. 
Part Three explains transfer pricing and tax implications. Part Four presents the analysis of disclosure of transfer pricing and taxation implication in Malaysian's segmental reporting environment. Part Five further discusses the issues and finally, Part Six provides overall conclusion on the issue.

Figure 1:

Objective of Domestic and International Transfer Pricing

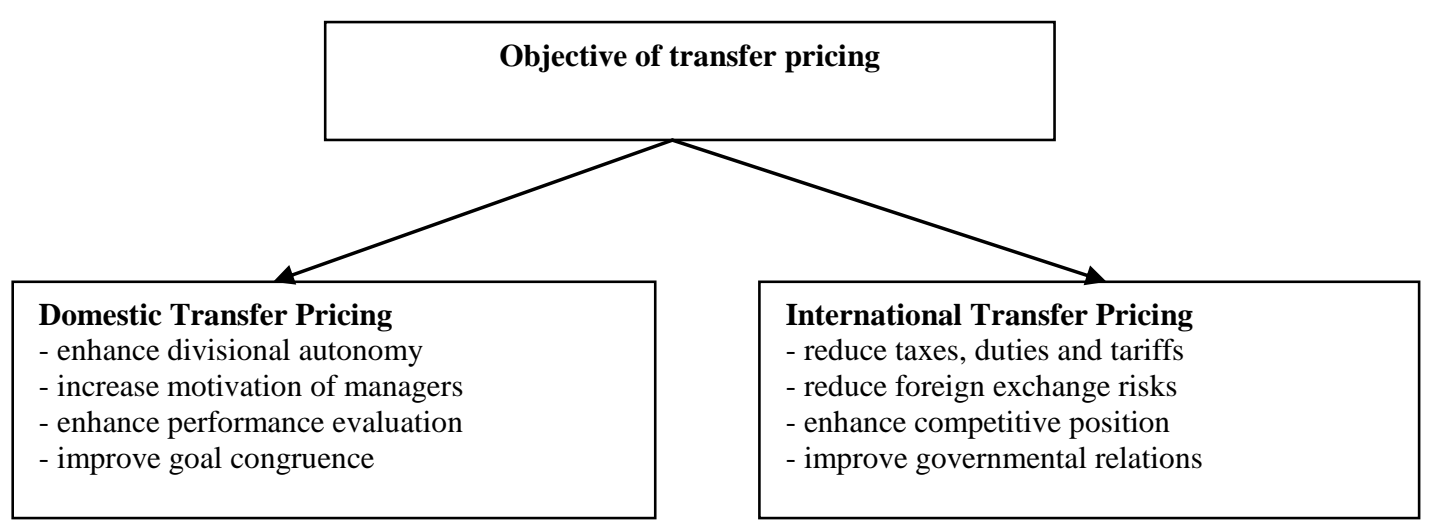

Source: Garrison and Noreen, 2000

\section{THEORY OF TRANSFER PRICING}

An important outcome of the growth of multinational companies is that much of the world's trade takes place within companies located in various countries. The prices at which the transactions take place are transfer prices. Transfer price has important implications for taxation, management control, and the relationships between such companies and their host countries. When the units are separate companies within a group, the transfer pricing is necessary for financial reporting and the calculation of taxable income. When the companies or units are in different tax jurisdictions, the issue becomes more important because of different accounting rules and tax rates.

Previous studies have been conducted in the area of transfer pricing. Arpan (1971) found use of market prices outside the United States. Tang (1979) found the popular use of a cost plus basis in the United States and Japan. Plasschaert (1985) meanwhile suggests that manipulation of transfer prices is more common in developing countries as governments are poorly equipped to monitor multinational companies. Jacob (1996) and Harris (1993) suggest that US-based multinational companies move income around the world in response to changes in tax rates. Researchers, tax authorities and managers are intensely interested in how transfer prices are set, since they can have a dramatic effect on the profitability of a division or unit within a group as well as tax collection. Three common approaches employed to set transfer prices are; (1) negotiated prices, (2) cost basis and (3) market price. In a survey of transfer pricing practice in large companies in Canada, Atkinson (1987) found that 85\% of the responding companies reported that they used transfer pricing. From the survey also proved that $57 \%$ of the responding companies adopted cost basis, $30 \%$ chose market price basis, $7 \%$ employed negotiated price basis and the remaining $6 \%$ chose other approaches.

\section{Negotiated price}

A negotiated transfer price is a transfer price that is agreed on between the selling and purchasing units. This approach preserves the autonomy of the units and is consistent with the aspiration of decentralization style of management. Secondly, the managers of the unit are likely to have much better information about the potential costs and benefits of the transfer than others in the company. As a negotiated price is employed, the concern managers are 
going to meet and discuss the appropriate terms and conditions of the transfer. They may decide not to go through with the transfer, but if they do, they must agree to a transfer price. The exact transfer price under such approach is very difficult to predict. However, the selling unit will agree to the transfer if the profits of the selling division increase as a result of the transfer and the purchasing unit agrees to the transfer if the profits of the purchasing unit also increase as a result of the transfer. Thus, the actual transfer price agreed by the two unit managers fall anywhere between these two assumptions or also known as the range of acceptable transfer price - the range of transfer price within which the profits of both units participating in a transfer price would increase (Garrison and Noreen, 2000). This assumption is graphically presented in Figure 2A and Figure 2B respectively.

Figure 2A:

Selling Unit's Minimum Acceptable Transfer Price

Transfer price $\geq$ Variable cost per unit $+\underline{\text { Total Contribution margin on lost sales }}$

Number of units transferred

Figure 2B:

Purchasing Unit's Maximum Acceptable Transfer Price

Transfer price $\leq$ Cost of buying from outside supplier

Source: Garrison and Noreen, 2000

However, negotiate transfer price consists of the following limitations; (1) time consuming for the managers involved as it takes longer time and thorough terms and conditions discussion before finalizing the exact price, (2) leads to conflict between units within a group, (3) makes the measurement of unit profitability sensitive to the negotiating skills of managers, (4) requires the time of top management to oversee the negotiating process and to mediate disputes and (5) leads to a suboptimal level of output if the negotiated price is above the opportunity cost of supplying the transferred goods.

\section{Cost basis}

Companies may also set transfer prices at either the variable cost or full cost basis incurred by the selling units. However, setting transfer price at cost basis has various disadvantages. First, the use of cost particularly full cost basis as a transfer price can lead to bad decisions and sub-optimization. Full cost or absorption cost approach provides a varying transfer price since the cost per unit is constantly changing as capacity use varies. Besides, mixing the short run and long run components of costs, it obscures the underlying cost structure from decision makers in the organization and therefore fails to suggest how cost savings can be obtained by using capacity more efficiently. In addition, the full cost approach is often implemented by using a formula approach that takes a variable cost and adds an arbitrary markup to cover capacity-related costs and perhaps a targeted profit margin (Kaplan and Atkinson, 1998). Secondly, if cost is used as the transfer price, the selling unit will never show a profit on any internal transaction. The only unit that shows a profit is the division that makes the final sale to external parties. Thirdly, cost-based transfer price does not provide incentives to control costs. If the costs of one unit are simply passed on the next, then there is little incentive for anyone to work to reduce costs. Despite, the disadvantages, cost-based transfer price are commonly employed in practice.

\section{Market price}

Transfer pricing based on competitive market price is considered as the best approach to transfer pricing problem. The conditions of a highly competitive market imply that the producing division can sell as much of the product as it wishes to outside customers, and the purchasing division can acquire as much as it wishes from outside 
vendors without affecting the price. In this matter, the market provides an objective valuation of the intermediate product, and that price should be used as basis for price transfers and guide within the firm.

If the purchasing division cannot make a long-run profit at the outside market price, then the company is better off to not produce the product internally and to go to the external market for its supply. Similarly, if the purchasing division cannot make a long-run profit when it must acquire the product at the external price, the division should cease acquiring and processing this product and should allow the producing unit to sell all its output to the external market. With a competitive market for the intermediate product, the market price provides an excellent basis for allowing the decisions of the producing and purchasing divisions to be independent of each other (Solomons, 1965).

However, conflict may incur when the price for the intermediate product or service is quoted on both a longterm contract and a spot market basis. When the market is not perfectly competitive, as it usually is not for most manufactured goods, the transfer price problem becomes much more complicated. In addition, conflict also arises between short run and long run considerations. An external vendor may quote a low price in an attempt to buy into the business, with the exception of raising prices later. The company normally should not switch its source of supply from an internal unit to an outside company unless it is confident that the outside company has the potential to maintain the quoted price for a substantial period. Shortly, none of the proposed solutions to transfer pricing problem are perfect including market-based transfer price. (Garrison et al., 2000).

\section{TRANSFER PRICING AND TAX IMPLICATIONS}

Definitely, tax authorities are alert to the problem of transfer pricing, which has become more important as globalization proceeds. Therefore, governments have empowered tax authorities to make adjustments to the calculation of taxable income in order to correct transfer that are not at arm's length. In United States for example, Section 482 of the Internal Revenue Code, which is the basic transfer pricing rule, has led to many regulations and tax cases. The outcome of the adjustments may be there is double taxation of some income of multinational companies. In some cases, governments have taken a different approach and required apportionment of worldwide profits of such companies (the unitary method). However, there is no international consensus on this rather broad-brush approach (Nobes and Parker, 2000). So, as to add order to this area, governments have made tax treaties with each other on the subject of transfer prices. These are generally based on model tax treaties, such as those prepared by the Organization for Economic Co-operation and Development (OECD, 1979) and the United Nations.

Taxes introduce another layer of complexity into transfer pricing. Consider an organization that manufactures products Country X, which has a marginal tax rate of $20 \%$, and sells those products in Country Y, which has a marginal tax rate of $30 \%$. Obviously, this organization would like to locate most of its profits in Country X, where the tax rate is lowest. Therefore, it will want to use the highest possible transfer price for the commodity. As example, the particular manufacturing company may set high transfer prices for intra group goods sold from Country $\mathrm{Y}$ to Country $\mathrm{X}$. Besides transfer pricing practice, the charging of royalties, interest of management fees is another mechanism for moving profits. For many companies, these tax considerations outweigh the behavioral considerations in setting a transfer price, and transfer pricing policy is driven by the objective of minimizing global taxes.

Needless to say, tax authorities understand this incentive and have taken steps to moderate companies' behavior. The tax authority in each country scrutinizes the international transfer pricing policies of companies doing business in that country to ensure that these companies are not using arbitrary transfer prices to avoid paying local taxes. The most important document relating to international transfer pricing is the 1995 Organization for Economic Co-Operation and Development guidelines statement. This document provides the foundation that many nations use to develop their individual tax laws that regulate transfer pricing behavior for companies that do business in their respective countries. The OECD guidelines divide transfer pricing practice into two main groups (refer Table 1). OECD guidelines state that, whenever possible, the CUP method, which uses either the market price or an imputed market price, should be employed. If there is no market price, preference falls to cost-plus basis. 
Table 1:

OECD's Transfer Pricing Group

\begin{tabular}{|l|l|}
\hline \multicolumn{1}{|c|}{ Transaction Group } & \multicolumn{1}{c|}{ Other Method } \\
\hline $\begin{array}{l}\text { a. Comparable uncontrolled price (CUP) } \\
\text { b. Cost - plus }\end{array}$ & $\begin{array}{l}\text { a. Profit Splits } \\
\text { b. Transactional net margin method } \\
\text { c. Resale price methods. }\end{array}$ \\
$\begin{array}{l}\text { c. Other approaches that are related to } \\
\text { partitioning the profits from trading }\end{array}$ \\
\hline
\end{tabular}

Studies of practice suggest that the cost-plus method of transfer pricing is the most widely employed for domestic transfer pricing, where as market price method is widely used for international transfer pricing. If given free choice, companies that use market prices to meet international transfer pricing requirements would switch to cost-plus methods. Alternatively, there is a group of companies that swing from using cost-based transfer price to market-based transfer price in the presence of a tax authority (Kaplan and Atkinson, 1998). The results of these studies may mean that companies use market-based transfer prices to meet the requirement of tax authorities because they are to the companies' advantage. However, the companies do not really believe that the profit signals provided by these market prices are meaningful, so they prefer to use cost-based methods for internal decision-making. Other than this interesting finding, it is instructive to observe how tax authorities interpret the cost component of a cost-based transfer price. It appears that most tax authorities allow companies to use whatever costing systems their external auditors have certified as conforming to Generally Accepted Accounting Principles (GAAP). As GAAP was designed for external reporting purposes, and not for making sound economic operating decisions, it permits a huge variation in costing practice. Such flexibility creates an opening for opportunistic behavior by companies to select tax minimizing methods when computing a cost-based transfer price.

Transfer pricing also leaves implication and question on who should bear the burden of the corporate tax? Will it be the owners of business or customers or workers of companies? Many economists believe that workers and customers bear much of the burden of the corporate income tax. As an example, suppose Country X decides to raise the tax on the income earned by automotive companies. At first, this tax hurts the owners of the car companies, who receive less profit. But, over time, these owners respond to the tax. Because producing cars is less profitable, they invest less in building new automotive plant or invest less in technological improvement or invest in other country who offer lower marginal tax rate. With fewer plants mean fewer productions, the supply of cars declines, as does the demand for automotive workers. Thus, an increasing tax on automotive companies causes the prices of cars to rise and the wages of automotive workers to fall. To get worse, relocation of automotive plants to other countries cause less foreign direct investments in Country $\mathrm{X}$ and may cause social instability due to high unemployment rate. Transfer pricing implication on corporate income tax shows how dangerous the flypaper theory of tax incident can be. The corporate income tax is popular because it appears to be paid by rich corporations. Yet those who bear the ultimate burden of the tax - the customers and workers of companies - are often not rich.

\section{TRANSFER PRICE AND TAXATION IMPLICATION DISCLOSURE}

A study has been carried out to investigate transfer price and taxation disclosure in segmental reporting among 80 Malaysian public listed companies. These companies are listed in First Board of Malaysian Bourse under industrial product, consumer product and trade/service sub sector. The annual reports of 2002 of those companies are reviewed twice for this study. The list of under studies companies is given as in Appendix 1. The descriptive analyses of those companies are summarized in Table 2A and 2B.

Table 2A: Sub Sector

\begin{tabular}{|c|c|}
\hline Sub - Sector & Number of Companies \\
\hline Industrial Product & $30(37.5 \%)$ \\
\hline Consumer Product & $21(26.25 \%)$ \\
\hline Trade \& Service & $29(36.25 \%)$ \\
\hline Total & $80(100 \%)$ \\
\hline
\end{tabular}


Table 2B: Segment Disclosure

\begin{tabular}{|c|c|c|c|}
\hline \multicolumn{3}{|c|}{$\boldsymbol{N = 8 0}$} \\
\hline Sub - Sector & $\begin{array}{c}\text { Disclose both Business } \\
\text { Segment and Geographic } \\
\text { Segment }\end{array}$ & $\begin{array}{c}\text { Disclose Business Segment } \\
\text { Only }\end{array}$ & $\begin{array}{c}\text { Disclose Geographic } \\
\text { Segment Only }\end{array}$ \\
\hline Industrial Product & $20(25 \%)$ & $9(11.25 \%)$ & $1(1.25 \%)$ \\
\hline Consumer Product & $12(15 \%)$ & $7(8.75 \%)$ & $2(2.5 \%)$ \\
\hline Trade \& Service & $14(17.5 \%)$ & $15(18.75)$ & $0(0.0 \%)$ \\
\hline Total & $46(57.5 \%)$ & $31(38.75 \%)$ & $3(3.75 \%)$ \\
\hline
\end{tabular}

Results of Table 2B reveals that 46 companies chose to disclose both business segment and geographic segment. 31 companies disclose only business segment and only 3 companies disclose geographic segment. Business segment is defined as a distinguishable component of a company that is engaged in providing an individual product or service or related products or services and that is subject to risks and returns that are different from those of other business segments (MASB, 2002). Meanwhile, geographic segment is defined as a distinguishable component of a company that is engaged in providing products or services within a particular economic environment and it is subject to risks and returns that are different from those of components operating in other economic environments (MASB, 2002). The less number of companies disclosing geographic segment is in line with previous study by Edwards and Garrod (1996) and Prodhan and Harris (1986), which revealed that geographical segment disclosure is identified as sensitive information, particularly for companies where a large contract may be its only operation in that location and may be the only contract within a large geographical area.

Table 2C: Transfer Pricing Approaches

\begin{tabular}{|c|c|c|c|c|}
\hline \multicolumn{5}{|c|}{$\boldsymbol{N = 8 0}$} \\
\hline Sub - Sector & $\begin{array}{c}\text { Market } \\
\text { Basis }\end{array}$ & $\begin{array}{c}\text { Cost } \\
\text { Basis }\end{array}$ & Negotiated Basis & $\begin{array}{c}\text { Not } \\
\text { Disclose }\end{array}$ \\
\hline Industrial Product & $9(11.25 \%)$ & $2(2.5 \%)$ & $11(13.75 \%)$ & $8(10 \%)$ \\
\hline Consumer Product & $11(13.75 \%)$ & $3(3.75 \%)$ & $1(1.25 \%)$ & $6(7.5 \%)$ \\
\hline Trade \& Service & $22(27.5 \%)$ & $1(1.25 \%)$ & $5(6.25 \%)$ & $1(1.25 \%)$ \\
\hline Total & $42(52.5 \%)$ & $6(7.5 \%)$ & $17(21.25 \%)$ & $15(18.75 \%)$ \\
\hline
\end{tabular}

Results of Table 2C proved that majority of companies $(52.5 \%)$ adopt market price basis as transfer pricing. Market price reflects an objective valuation of the intermediate product and it guides decision making process within firm. In addition, market price provides better divisional performance evaluation compared of using other approaches especially negotiated price basis. Only 17 companies adopt negotiated transfer pricing style. Majority of them are listed as industrial product companies. The six other companies adopt cost basis transfer pricing particularly among consumer product companies, whereas the fifteen companies do not indicate their transfer pricing approaches.

Table 2D: Taxation Disclosure

\begin{tabular}{|c|c|c|c|}
\hline \multicolumn{5}{|c|}{$\boldsymbol{N = 8 0}$} \\
\hline Sub - Sector & $\begin{array}{c}\text { Taxation Disclosure in } \\
\text { Segment Results Only } \\
\text { Tndustrial Product }\end{array}$ & $\begin{array}{c}\text { Taxation Disclosure in } \\
\text { Segment Results, Segment } \\
\text { Assets and Segment } \\
\text { Liabilities }\end{array}$ & No Taxation Disclosure \\
\hline Consumer Product & $21(26.25 \%)$ & $7(8.75 \%)$ & $2(2.5 \%)$ \\
\hline Trade \& Service & $18(22.5 \%)$ & $3(3.75 \%)$ & 0 \\
\hline Total & $25(31.25 \%)$ & $4(5.0 \%)$ & 0 \\
\hline
\end{tabular}


Result of Table 2D reveals that 64 companies $(80 \%)$ disclose taxation implication in segment results. Segment result shows segment revenue and segment expense. The only taxation implication discloses in segment results is income tax expense, earnings before interest and income tax (EBIT) and earnings after income tax (EAT). Segment assets is defined as the operating assets that are employed by a segment in its operating activities and that either are directly attributable to the segment or can be allocated to the segment on a reasonable basis (MASB, 2002). Segment liabilities are defined as the operating liabilities that result from the operating activities of a segment and that either are directly attributable to the segment or can be allocated to the segment on a reasonable basis (MASB, 2002). Taxation implication recorded in segment assets consist of income tax assets and tax recoverable. Whereas taxation implication recorded in segment liabilities include of income tax liabilities, tax payable and deferred taxation

\section{DISCUSSION AND ANALYSIS}

It cannot be denied that companies nowadays go for business diversification and geographical diversification. These activities demand more than consolidated financial statement in order to thoroughly evaluate each business segment and geographic segment performance. The answer to these demands is segmental information disclosure. As companies attempt to take advantage on the different rates of returns, risks and growth opportunities, each unit or division within a company's group has been located differently. For instance oil and gas company like Exxon Mobil has refining division in country $\mathrm{M}$, which processes crude oil into gasoline, kerosene, lubricants and other end product. Those products later are sold to retail sales division in country, for instance; Thailand, Singapore and Philippines before being distributed to Exxon Mobil's chain of petrol station in respective countries. Each product has a price for transfers within the company. Clearly the refining division would like the transfer price to be as maximum possible, meanwhile the retail division would like the transfer price to be as low as possible. Such transfer pricing will be more significant and has greater taxation implication if the products move from one geographical area to another geographical boundary with different taxation system, tax rate and tax charges.

Therefore, question raises whether segmental reporting adequately disclose transfer pricing practice and record its taxation implications? Many quarters need segmental information to enhance the evaluation and decisionmaking process pertaining transfer pricing activities. Definitely the host government needs segmental information to access its taxation system implication on the companies operation. Would the companies' management happy with the current taxation impose or they are not happy thus thinking of relocating its operation in other countries who offer lower tax rate? Unit or division's managers also need segmental report in order to evaluate their own performance. Would to low transfer price harms its revenue and would to exorbitant transfer price distort its costing? In addition, employees and external suppliers are also keen with transfer pricing disclosure in segmental reporting, as it directly involve their performance assessment and business opportunities respectively.

A study has been conducted to evaluate transfer pricing and its taxation implication disclosure in 80 companies listed at Malaysian Bourse. Those companies are classified as industrial product sub sector, trade \& service sub sector and consumer product sub sector. Those companies has diversified their business operation and also conducting businesses in different countries. An analysis found that those companies disclose the basis of transfer price as segmental reporting voluntary disclosure. As indicated in Table $2 \mathrm{C}$, most companies choose market price as the basis of transfer pricing. The figure of transfer pricing is also clearly reported in segment revenue, as the companies derive net external revenue, which is equivalent to net revenue figure in consolidated financial statement. This is graphically presented in following Figure 3 . However, the companies in the study only reveals transfer pricing or inter - segment sales in their business segment only and no such disclosure in geographic segment.

On taxation implication due to transfer pricing, such disclosure are also inadequate. The income tax disclosure is a consolidated figure, which equals to tax figure in group of company's consolidated financial statement. As far as the study concern, only one company discloses income tax implication at each different business segment before arriving at consolidated taxation figure. This pattern also applies when the company discloses taxation implication in segment assets and segment liabilities. In addition, taxation implications are being disclosed only in business segment and no such disclosure in geographic segment. 
Figure 3:

Inter - Segment Disclosure of Malayan Cement Berhad 2002

\begin{tabular}{|l|c|c|c|c|c|c|}
\hline \multicolumn{1}{|c|}{ Group } & $\begin{array}{c}\text { Cement \& } \\
\text { Clinker } \\
\text { RM'000 }\end{array}$ & $\begin{array}{c}\text { Other } \\
\text { Building } \\
\text { Materials } \\
\text { RM'000 }\end{array}$ & $\begin{array}{c}\text { Readymix } \\
\text { Concrete } \\
\text { RM'000 }\end{array}$ & $\begin{array}{c}\text { Other } \\
\text { Operation } \\
\text { RM'000 }\end{array}$ & $\begin{array}{c}\text { Elimination } \\
\text { RM'000 }\end{array}$ & $\begin{array}{c}\text { Consolidated } \\
\text { RM'000 }\end{array}$ \\
\hline Revenue & & & & & & \\
\hline External Sales & $1,045,824$ & 202,968 & 401,601 & 23,612 & & $1,674,005$ \\
\hline \begin{tabular}{l|l|l|l|l|l|} 
Inter-segment \\
sales
\end{tabular} & 146,607 & 4,148 & 6,430 & 17,735 & $(174,920)$ & - \\
\hline Total revenue & $1,192,431$ & 207,116 & 408,031 & 41,347 & $(174,920)$ & $1,674,005$ \\
\hline
\end{tabular}

\section{SUMMARY AND CONCLUSION}

From the above discussion, it has been concluded that transfer pricing is common practice in highly diversified companies as they attempt to grab different rate of return, risks and opportunities growth. Transfer pricing has two major forms that are domestic transfer pricing and international transfer pricing. While domestic transfer pricing aims to enhance divisional autonomy, international transfer pricing has significant implication on taxation, duties and excise as well as enhancing governmental relations.

In investigating the transfer pricing and its tax implication disclosure in Malaysian companies' segmental reporting, the study showed that companies disclose the basis of transfer price. However, such disclosure is not adequate in order to assist interested parties in performance evaluating process and in decision-making process. These inadequacies are as follows:

- The reporting transfer pricing is disclosed only in business segment.

- $\quad$ The taxation implication is disclosed only at consolidated figure.

- Transfer pricing and taxation implication disclosure is considered as voluntary disclosure and not as mandated disclosure by Malaysian Accounting Standards Board (MASB).

Realizing the importance of segmental information disclosure in evaluating process and decision making process, such disclosure should also be improved in order to facilitate the record on transfer pricing practice and its taxation implication. One of the best ways is imposing transfer pricing and taxation implication disclosure in segmental reporting as the mandated disclosure. However, such amendment shall only be done after thorough discussion with accounting standard setter bodies, taxation authorities and the reporting companies. Some reporting companies believe too much segmental disclosure especially in geographic segment may cause competitive disadvantage and harm their performance. The study can also be extended in future by expanding the number of sample in order to obtain significant generalization. Secondly, it can also be extended to analysis the behavioral aspect of segmental reporting preparers especially why they prefer to disclose transfer pricing and taxation implication in business segment and not in geographic segment. In addition, further study can also be applied in other countries in order to provide comprehensive cross analysis and comparison insights. In fact such studies can significantly contribute towards harmonization of segmental reporting disclosure with regard to international transfer pricing practices and its taxation implication.

\section{REFERENCES}

1. Arpan, J.S. (1971). International intracorporate pricing: non-American systems and Views. New York: Prager.

2. Atkinson, A. (1987). Intra-firm cost and resource allocation: theory and practice. Toronto: Canadian Academic Accounting Association.

3. Financial Accounting Standard Board [FASB]. (1976). Statement of financial accounting standards SFAS No. 14: Financial reporting for segments of a business enterprise. Stanford: FASB. 
4. Garrison, R.H. \& Noreen, E.W. (2000). Managerial Accounting International Edition. (9th ed.). Boston: Irwin-McGraw Hill.

5. Garrod. N. (2000). Competitive disadvantage and segmental disclosure. Glasgow: Department of Accounting and Finance, University of Glasgow.

6. Gray, S.J. \& Roberts, C.B. (1989). Voluntary information disclosures and the British multinationals. In Hopwood, A.G. (Eds.), International Pressure for Accounting Change. New York: Prentice Hall.

7. Harris, D.G. (1993). The impact of US tax law revision on multinational corporations' capital location and income shifting decisions. Journal of Accounting Research. Vol. 31 (Supplement)

8. Jacob, J. (1996). Taxes and transfer pricing: income shifting and the volume of intrafirm transfer. Journal of Accounting Research Vol. 34, No. 2 (Fall).

9. Kaplan, R.S. \& Atkinson, A.A. (1998) Advanced Management Accounting International Edition (3rd ed). New Jersey: Prentice Hall.

10. Malaysian Accounting Standard Board [MASB]. (2002). MASB 22: Segment Reporting. Kuala Lumpur: MASB.

11. Nobes, C. \& Parker, R. (2000). Comparative International Accounting (6th ed.). London: Financial Times-Prentice Hall.

12. Organization for Economic Co-Operation and Development [OECD]. (1995) Transfer Pricing Guidelines for Multinational Enterprises and Tax Administrations. Paris: OECD

13. Organization for Economic Co-Operation and Development [OECD]. (1979) Transfer Pricing and Multinational Enterprises. Paris: OECD

14. Plasschaert, S.R.F. (1985). Transfer pricing problems in developing countries. In A.M. Rugman and L. Eden (end), Multinationals and transfer pricing. New York: St. Martin Press.

15. Radebaugh, L.H. \& Gray, S.J. (2002). International Accounting Multinational Enterprise (5th ed.). New York: Wiley.

16. Reed, R. \& Luffman, G. (1986). Diversification: The growing confusion. Strategic Management Journal, Volume 3, 359369.

17. Ronen, J. \& Livnat, J. (1981). Incentives for segment reporting. Journal of Accounting Research, 19, 459-481.

18. Solomon, D. (1965). Divisional performance: Measurement and control. Illinois: Dow Jones-Irwin.

19. Solomons, D. (1989). Guidelines for financial reporting standard. London: Institute of Chartered Accountant of England and Wales.

20. Tang, R.Y.W. (1979). Transfer pricing practices in the United States and Japan. New York: Praeger.

\section{APPENDIX 1: LIST OF COMPANIES}

Uchi Technology

Ta Ann Holdings

Sunway Building Technology

Thong Guan Industries

PSC Industries

Linear Corporation

Kian Joo Can Factory

Dijaya Corporation

CHG Industry

TSH Resources

Paracorp Bhd

Pan Malaysia Corporation

Muda Holdings

Malayan Cement

Leader Universal Holdings

Keck Seng Holdings

Grand United Holdings

Ho Wah Genting

Ramatex Berhad

Kim Hin Industry

Hexza Group

Resorts World

Paos Holdings

Sindora Berhad

Wembley Industries Holdings

Press Metal Berhad

Sarawak Enterprise Corporation
FFM Berhad

Yeo Hiap Seng

KLG Glass Industrial

Jerasia Capital

Mintye Industries

Sin Heng Chan

I - Berhad

CSM Corporation

Ayamas Food Corporation

Yee Lee Corporation

Pernas International

Naluri Berhad

Sime Darby

Genting Berhad

Integrated Logistics Berhad

Kumpulan Emas

Magnum Corporation

Malayan United Industries

MBM Resources

Mechmar Corporation

Mulpha Corporation

Construction and Supplies House

Telekom Malaysia

Texchem Resources

Marco Holdings

Utusan Melayu
Fraser \& Neave Holdings

UMW Holdings

MWE Holdings

Oriental Holdings

Nikko Electronics

Mamee Double Decker

Malaysia Flour Mill

Diethelm Holdings

Arus Murni Corporation

Bousted Holdings

Multi Purpose Holdings

EOX Group

Metacorp Berhad

Minho Berhad

Goh Ban Huat

Delloyd Ventures

KUB Malaysia

Lii Hoe Industries

KFC Holdings

Golden Pharos

Time Engineering

Sri Wani Holdings

Chemical Company of Malaysia

Fiamma Holdings

Inti Universal Holdigns

Konsortium Logistic Berhad 